SZYMON TARAPATA

Uniwersytet Jagielloński

\title{
ROZWAŻANIA O USTALANIU SĄDU WŁAŚCIWEGO DO WSTRZYMANIA WYKONANIA WYROKU W ZWIĄZKU ZE ZŁOŻENIEM WNIOSKU O UDZIELENIE ZEZWOLENIA NA ODBYWANIE KARY POZBAWIENIA WOLNOŚCI W SYSTEMIE DOZORU ELEKTRONICZNEGO
}

Problematyka ustalania właściwości sądu w postępowaniu wykonawczym jest jednym z najtrudniejszych zagadnień dla dogmatyki i praktyki prawa karnego wykonawczego ${ }^{1}$. Często się zdarza, że jedno orzeczenie jest egzekwowane przez dwa lub więcej organy sądowe (lub pozasądowe). Ogólna zasada dotycząca ustalania właściwości sądu w postępowaniu wykonawczym została sformułowana w art. $3 \$ 1$ k.k.w. Przepis ten stanowi, że: „Sąd, który wydał orzeczenie w pierwszej instancji, jest właściwy również w postępowaniu dotyczącym wykonania tego orzeczenia, chyba że ustawa stanowi inaczej”. Aktualnie ustawodawca przewiduje jednak wiele wyjątków od tej zasady. Jeden z nich wynika $\mathrm{z}$ art. 43e $\$ 1$ k.k.w., który przewiduje, że w sprawach o udzielenie zezwolenia na odbywanie kary pozbawienia wolności w systemie dozoru elektronicznego (dalej: „SDE”) właściwy jest sąd penitencjarny, w którego okręgu skazany przebywa.

Wspomniane wyżej zróżnicowanie dotyczące właściwości organów jurysdykcyjnych rodzi liczne trudności praktyczne. Wynikają one zasadniczo z faktu, że złożenie wniosku o zezwolenie na udzielenie zgody

1 Por. K. Postulski, Właściwość sądu w postępowaniu karnym wykonawczym, «Prokuratura i Prawo» 5/2010, s. 54-76. 
na odbywanie kary pozbawienia wolności w SDE nie wstrzymuje wykonania tej sankcji ${ }^{2}$. Wstrzymanie takie może nastąpić dopiero wówczas, gdy w realiach danej sprawy dojdzie do zastosowania art. $9 \$ 4$ k.k.w. Stosownie do tej regulacji - złożenie wniosku o wydanie postanowienia w postępowaniu wykonawczym nie wstrzymuje wykonania orzeczenia, którego wniosek dotyczy, chyba że sąd, w szczególnie uzasadnionych wypadkach, postanowi inaczej. Orzeczenie takie jest niezaskarżalne i nie wymaga uzasadnienia.

Na podstawie samego art. $9 \$ 4$ k.k.w. nie sposób stwierdzić jednak, który sąd jest właściwy do wstrzymania wyroku w sytuacji, gdy złożono do sądu penitencjarnego wniosek o zezwolenie na odbywanie kary pozbawienia wolności w SDE. W praktyce napotkać można przynajmniej dwa alternatywne rozwiązania tej kwestii. W ramach pierwszego przyjmuje się, że to sąd penitencjarny jest uprawniony do tego, by - przed rozpoznaniem wniosku o udzielenie zezwolenia na odbywanie kary w SDE - wstrzymać wykonanie wyroku w zakresie dotyczącym sankcji izolacyjnej³.

Wskazane rozwiązanie jest jednak często kwestionowane. Z drugiej strony twierdzi się bowiem, że aby powstrzymać procedurę osadzenia w jednostce penitencjarnej, należy, wraz z wnioskowaniem o udzielenie zezwolenia na odbywanie kary w SDE, złożyć osobny wniosek do sądu pierwszej instancji o wstrzymanie wykonania wyroku w zakresie kary pozbawienia wolności (załączając jednocześnie odpis wniosku o zezwolenie na odbywanie kary w SDE i załączników) ${ }^{4}$. Celem niniejszego opracowania jest udzielenie odpowiedzi na pytanie, które z prezentowanych rozwiązań jest de lege lata prawidłowe.

Przed przystąpieniem do najważniejszych dla tego tekstu rozważań warto jeszcze wskazać, że w praktyce można napotkać sytuacje, w których z jednej strony skazany lub jego obrońca wnioskuje do sądu

2 Stosownie bowiem do art. $9 \$ 2$ k.k.w., wyrok staje się wykonalny z chwilą jego uprawomocnienia (por. też M. Kuć, Prawo karne wykonawcze, Warszawa 2017, s. 56-57).

3 Na takie rozwiązanie zdecydował się SO w Krakowie, wstrzymując wykonanie wyroku na mocy postanowienia z 15 grudnia 2014 r., V Kow 2757/14 (niepubl.).

4 Tak uczynił chociażby SR Wrocław-Krzyki, wydając postanowienia z 14 grudnia 2018 r., VII 2 Ko 3224/18, oraz z 4 października 2018 r., VII 2 Ko 2716/18 w sprawie wstrzymania wyroku (niepubl.). 
penitencjarnego o zezwolenie na odbywanie kary pozbawienia wolności w SDE, z drugiej zaś składa wniosek do sądu pierwszej instancji, w którym domaga się wstrzymania wykonania wyroku i wnosi o odroczenie wykonania sankcji izolacyjnej (powołując się na fakt złożenia do sądu penitencjarnego wniosku o zezwolenie na odbywanie kary pozbawienia wolności w systemie dozoru elektronicznego). Taki sposób postępowania w znakomitej większości przypadków musi budzić uzasadnione wątpliwości. Wynikają one z tego, że sam fakt złożenia wniosku o zezwolenie na odbywanie kary pozbawienia wolności w SDE nie jest okolicznością, o której mowa w art. 150 i 151 k.k.w. Do wydania zgody na dozór muszą zostać spełnione autonomiczne przesłanki, określone w art. 43h i 43la k.k.w. Z tego też powodu, jeśli niezwłoczne wykonanie kary pozbawienia wolności nie pociągnęłoby dla skazanego lub jego rodziny zbyt ciężkich skutków (oraz gdy skazany nie cierpi na chorobę psychiczną lub inną ciężką chorobę uniemożliwiającą wykonanie kary pozbawienia wolności), wówczas nie ma żadnych racji, by wstrzymywać wykonanie wyroku w związku ze złożeniem wniosku o zezwolenie na wykonanie kary pozbawienia wolności w SDE. Patrząc jednak na to zagadnienie z nieco innej perspektywy, nie można oczywiście wykluczyć przypadku, kiedy powody, o których mowa w art. 150 i 151 k.k.w., nie będą istnieć w przypadku egzekwowania sankcji izolacyjnej w warunkach dozoru, wystąpią zaś w razie realizacji izolacji w formie osadzenia w jednostce penitencjarnej. Da się przyjąć, że w takim układzie sytuacyjnym możliwe byłoby odroczenie wykonania kary pozbawienia wolności do czasu rozpoczęcia owego dozoru 5 .

5 Por. jednak postanowienie SA w Krakowie, II AKzw 1097/17, w który stwierdzono, że: „Sąd Apelacyjny stale stwierdza w swych orzeczeniach, że system dozoru elektronicznego nie służy łagodzeniu negatywnych skutków dla zdrowia czy sytuacji rodzinnej skazanego, związanych z jego osadzeniem w zakładzie karnym. Te sytuacje rozwiązuje się odroczeniem wykonania kary, a po jej rozpoczęciu - przerwy w karze" («Lex» nr 2566597). Wydaje się, że teza ta jest aktualna jedynie wówczas, gdy wydanie zezwolenia na odbycie kary pozbawienia wolności w SDE jest sprzeczne z celami tej sankcji. W takiej sytuacji należałoby udzielić odroczenia wykonania kary (lub przerwy w karze), zaś po jego upływie osadzić skazanego w jednostce penitencjarnej. Natomiast sąd penitencjarny w takich sytuacjach nie powinien wyrażać zgody na wdrożenie SDE. 
Można przypuszczać, że zasadniczy argument mający przemawiać za stanowiskiem, iż właściwy do wstrzymania wykonania wyroku w związku ze złożeniem wniosku o zezwolenie na egzekwowanie sankcji izolacyjnej w SDE jest sąd pierwszej instancji, stanowi przede wszystkim jedna okoliczność. Chodzi mianowicie o wynikające z przytoczonego już art. $3 \$ 1$ k.k.w. domniemanie, że za właściwy do wykonania orzeczenia winno się uznać sąd, który je wydał w pierwszej instancji. Presumpcja ta dotyczy też co do zasady wyroku skazującego w zakresie kary pozbawienia wolności. To właśnie sąd pierwszej instancji wzywa skazanego do stawienia się w wyznaczonym terminie w areszcie śledczym położonym najbliżej miejsca jego stałego pobytu lub poleca doprowadzenie go do jednostki penitencjarnej (art. $79 \$ 1$ i 2 k.k.w.). Ten sam organ jurysdykcyjny jest też władny między innymi, przy spełnieniu ustawowych przesłanek, by zawiesić lub umorzyć postępowanie wykonawcze w przedmiocie sankcji izolacyjnej. Oczywiście prawodawca wielokrotnie zastrzega kompetencje sądu penitencjarnego do wydawania określonych rozstrzygnięć w toku egzekwowania orzeczenia. Dotyczy to sytuacji wyraźnie przewidzianych w ustawie. Nie zmienia to jednak faktu, że to sąd pierwszej instancji należy traktować jako gospodarza postępowania wykonawczego w zakresie egzekwowania sankcji izolacyjnej ${ }^{6}$. Skoro więc jest on co do zasady jego dysponentem, to powinien być również właściwy do wstrzymania wykonania wyroku skazującego na karę pozbawienia wolności?

6 Niczego w tej kwestii nie zmienia fakt, że wiele czynności wykonywanych w postępowaniu w przedmiocie wykonania kary pozbawienia wolności nie wymaga formy postanowienia sądu. Przykładowo skierowanie wyroku do wykonania jest czynnością administracyjną, dokonywaną w postaci zarządzenia wydanego przez prezesa sądu lub upoważnionego sędziego (I. ZGoliński, [w:] Kodeks karny wykonawczy. Komentarz, red. J. LAchowski, Warszawa 2018, s. 67). Orzeczenia te mają bowiem charakter techniczny i są wydawane wewnątrz struktury sądu pierwszej instancji.

W pewnym sensie na ślad podobnego toku rozumowania można natrafić w wyroku SA w Katowicach z 15 maja 2018 r., II AKz 336/18. W sprawie tej rozważano, czy sąd okręgowy, który decyduje się na wydanie listu żelaznego, może wstrzymać uprzednio wydane przez inny sąd postanowienie o zastosowaniu tymczasowego aresztowania. W judykacie tym wskazano, że: „Obecny stan prawny nie wyklucza możliwości zastosowania listu żelaznego, w sytuacji uprzedniego wydania postanowienia w przedmiocie 
Ustawodawca w tekstach aktów prawnych często wskazuje organy, które są uprawnione do wstrzymania egzekucji danego orzeczenia. Przykładowo w art. $462 \$ 1$ k.p.k. zaznaczono, że wstrzymać wykonalne i zaskarżone zażaleniem postanowienie może zarówno sąd, który je wydał, jak i sąd powołany do rozpoznania zażalenia.

Warto również wspomnieć o art. $532 \$ 1$ k.p.k. Przepis ten przyznaje Sądowi Najwyższemu uprawnienie do wstrzymania orzeczenia zaskarżonego kasacją i innego orzeczenia, którego wykonanie zależy od rozstrzygnięcia kasacji. Podobne do art. $462 \$ 1$ k.p.k. uregulowanie znajduje się w art. $9 \$ 3$ k.k.w. Ostatni z przepisów stanowi, że wykonanie postanowienia $\mathrm{w}$ postępowaniu wykonawczym może wstrzymać sąd je wydający lub sąd powołany do rozpoznania zażalenia. Jak już natomiast wspomniano, w art. $9 \$ 4$ k.k.w. nie sprecyzowano, który organ procesowy może zablokować egzekucję orzeczenia. Z przepisu tego też nie wynika wyraźnie, że do dokonania takiej czynności uprawniony jest sąd właściwy do rozpoznania wniosku złożonego w postępowaniu wykonawczym (w tym wypadku wniosku o udzielenie zezwolenia na

zastosowania izolacyjnego środka zapobiegawczego, o ile tylko środek ten nie jest wykonywany w chwili procedowania w przedmiocie wydania listu żelaznego. Wydając list żelazny, sąd a quo nie jest władny wypowiadać się co do zasadności dalszego stosowania tymczasowego aresztowania ani tym bardziej do jego uchylenia. W takiej sytuacji, o ile sąd meriti rozpoznający sprawę uznałby, iż wnioski obrońcy o wydanie listu żelaznego zasługują na uwzględnienie, winien przesłać odpis zapadłego w tym przedmiocie orzeczenia do właściwego Sądu Rejonowego, który zastosował wobec podejrzanego areszt tymczasowy, celem podjęcia przez tenże sąd decyzji procesowej o wstrzymaniu wykonania postanowienia o zastosowaniu tego środka zapobiegawczego - stosownie do treści art. $9 \$ 3$ k.k.w. - a następnie wycofania związanej z tym dokumentacji wykonawczej oraz prokuratorowi w celu odwołania poszukiwań listem gończym. Omawiane rozwiązanie ma również ten skutek, iż niedochowanie przez stronę warunków wydania listu żelaznego skutkować będzie jego odwołaniem, a po wydaniu postanowienia w trybie art. $282 \$ 2$ k.p.k., nie będzie konieczności ponownego procedowania w przedmiocie zastosowania tymczasowego aresztowania (które nie zostało przecież uchylone), a wyłącznie podjęcie działań w kierunku jego wykonania” («Lex» nr 2556140). Wydaje się jednak, że z uwagi na specyficzne funkcje postanowień o tymczasowym aresztowaniu oraz wydaniu listu żelaznego rozważań zawartych w cytowanym orzeczeniu nie da się bezpośrednio przełożyć na problem omawiany w niniejszym opracowaniu. 
odbywanie kary pozbawienia wolności w SDE). Co jednak istotniejsze, literalne brzmienie art. $9 \$ 4$ k.k.w. przyznania takiego uprawnienia wspomnianemu organowi procesowemu wcale nie wyklucza.

Wstrzymaniu wykonania wyroku przez sąd penitencjarny w związku ze złożeniem wniosku o wyrażenie zgody na odbywanie kary pozbawienia wolności w SDE nie sprzeciwia się również formuła zawarta w art. $242 \$ 4$ k.k.w. W tej części słowniczka wyrażeń ustawowych wskazano, że określenie ,,sąd” bez bliższego sprecyzowania na potrzeby kodeksu karnego wykonawczego oznacza sąd powszechny lub wojskowy określony w art. $3 \$ 1$ k.k.w. (a więc sąd, który wydał orzeczenie w pierwszej instancji). W dalszym fragmencie art. $242 \$ 4$ k.k.w. wyraźnie zastrzeżono jednak, że odpowiednio do sądu penitencjarnego stosuje się między innymi art. $9 \$ 4$ k.k.w. Ostatni z przywołanych przepisów został jednak dodany do katalogu określonego w art. $242 \$ 4$ k.k.w. in fine dopiero z dniem 5 października 2019 r. Nastąpiło to za sprawą art. 2 pkt 5 ustawy z 19 lipca 2019 r. o zmianie ustawy - Kodeks postępowania karnego oraz niektórych innych ustaw ${ }^{8}$. W uzasadnieniu do tejże noweli wskazano, że: „Zmiana treści $\$ 4 \mathrm{w}$ art. 242 k.k.w. daje sądowi penitencjarnemu możliwość wstrzymania wykonalności postanowienia w postępowaniu wykonawczym. Brak jest racjonalnych powodów do różnicowania w tym zakresie uprawnienia sądu rejonowego i penitencjarnego"'. Wspomniana nowela niewątpliwie może stanowić silny argument przemawiający za tezą, że organ jurysdykcyjny wydający orzeczenie w przedmiocie zezwolenia na odbywanie sankcji izolacyjnej w SDE jest uprawniony do wstrzymania wykonania wyroku. Trzeba jednak przyznać, że przed dniem 5 października 2019 r. art. $242 \$ 4$ k.k.w. na zasadność takiego poglądu nie wskazywał (co jednak jeszcze nie oznacza, że tego zapatrywania nie dało się wówczas bronić).

Oczywiście można byłoby się pokusić o dokonanie zawężającej wykładni art. $242 \$ 4$ k.k.w. Dałoby się przykładowo twierdzić, że art. $9 \$ 4$ k.k.w. stosuje się odpowiednio do sądu penitencjarnego jedynie wówczas, gdy uwzględnienie danego wniosku musi skutkować

Dz U., poz. 1694.

9 Uzasadnienie projektu, druk sejmowy nr 3251, Sejm VIII kadencji, s. 76. 
uwolnieniem skazanego (tj. gdy kwestia zwolnienia skazanego mieści się w przedmiocie wszczętego postępowania). Chodziłoby tu więc przykładowo o orzeczenie w przedmiocie warunkowego przedterminowego zwolnienia lub przerwy w sankcji izolacyjnej ${ }^{10}$. Wstrzymanie wykonania wyroku w zakresie kary pozbawienia wolności nie byłoby możliwe natomiast wtedy, gdy postanowienie wydane na podstawie wniosku głównego (czyli takiego, któremu towarzyszył wniosek o wstrzymanie wykonania orzeczenia) nie może skutkować wydaniem decyzji „wolnościowej”. Ewidentnie tak dzieje się natomiast w przypadku wyrażenia zgody na odbywanie sankcji izolacyjnej w SDE. Rozpoczęcie dozoru nie powoduje bowiem, że skazany jest „uwalniany”. O zasadności takiej perspektywy upewnia stanowisko zaprezentowane w wyroku Sądu Najwyższego z 21 czerwca 2017 r. (I KZP 3/17) ${ }^{11}$. W judykacie tym wyraźnie zasugerowano, że od 15 kwietnia 2016 r., a więc od daty, w której dozór elektroniczny przestał być związany z karą ograniczenia wolności, pozbawienie wolności realizowane w tym systemie stało się sankcją izolacyjną. Można na tej podstawie twierdzić między innymi, że ktoś, kto sam uwalnia się z dozoru, może realizować znamiona typu $\mathrm{z}$ art. $242 \$ 1$ k.k. ${ }^{12}$ Jeśli chodzi natomiast o zasadniczy przedmiot rozważań, w analizowanej perspektywie można by twierdzić, że skoro postanowienie sądu penitencjarnego o udzieleniu zezwolenia na odbywanie kary pozbawienia wolności w SDE nie jest decyzją wolnościową, to ów organ jurysdykcyjny nie może być uprawniony do wstrzymania wykonania wyroku w zakresie sankcji izolacyjnej i uwolnienia skazanego.

10 W piśmiennictwie widoczna jest zresztą próba wykładania katalogu zawartego w art. $242 \$ 4$ k.k.w. w perspektywie przedmiotu zasadniczego postępowania, w związku z którym stosowane są przepisy wymienione w końcowej części przytoczonej regulacji. Sąd penitencjarny może przykładowo umorzyć postępowanie w przedmiocie odroczenia wykonania sankcji izolacyjnej, nie może zaś umorzyć całego postępowania dotyczącego wykonania kary pozbawienia wolności (por. J. Postulski, Właściwość..., s. 59).

11 «Legalis» nr 1651439.

12 Por. też A. GóRsKi, Wykonanie kary w systemie dozoru elektronicznego a przestępstwo samouwolnienia (uwagi na marginesie wyroku Sądu Najwyższego, I KZP 3/17), «iP» 74.4/2019, s. 79-87. 
Zaprezentowany w poprzednim akapicie pomysł wykładniczy mógłby jednak zostać zaakceptowany jedynie wtedy, gdyby istniały jakieś istotne racje natury aksjologicznej lub kryminalno-politycznej, przemawiające za tezą, by tylko sąd pierwszej instancji był wyłącznie właściwy do zastosowania art. $9 \$ 4$ k.k.w. w sytuacji, gdy złożono wniosek o egzekwowanie kary pozbawienia wolności w warunkach dozoru elektronicznego. Wydaje się jednak, że takowych argumentów zaprezentować nie sposób. Należy raczej twierdzić, że da się znaleźć istotne czynniki przemawiające za przeciwnym stanowiskiem.

Trzeba przede wszystkim zauważyć, że konieczność wstrzymania wykonania wyroku w związku ze złożeniem wniosku o udzielenie zezwolenia na odbywanie kary pozbawienia wolności w SDE do innego organu jurysdykcyjnego aniżeli sąd penitencjarny niewątpliwie w zasadniczej większości przypadków wydłuży proces powstrzymania egzekwowania sankcji izolacyjnej. W takich przypadkach zwiększa się też prawdopodobieństwo, że - zanim zostanie zastosowany art. $9 \$ 4$ k.k.w. - dojdzie już do osadzenia skazanego w jednostce penitencjarnej. Oczywiste jest zaś, że celem leżącym u podstaw przytoczonej regulacji jest właśnie to, by takiej konsekwencji uniknąć. Z punktu widzenia zasady szybkości postępowania optymalne jest rozwiązanie, w ramach którego to sąd penitencjarny posiadałby uprawnienie do wstrzymania wykonania wyroku w zakresie kary pozbawienia wolności. Patrząc z punktu widzenia pragmatycznego i prakseologicznego, nie ma, jak się wydaje, sensu angażowanie dodatkowego organu jurysdykcyjnego w sprawę integralnie związaną ze złożeniem wniosku o zastosowanie dozoru elektronicznego. Zatem wymaganie, by to sąd pierwszej instancji musiał w omawianych przypadkach wstrzymywać wykonanie wyroku, wydaje się sprzeczne z zasadą ekonomiki procesowej.

Dla rozstrzygnięcia problemu omawianego w niniejszym opracowaniu nie bez znaczenia jest ustalenie, jaki w ogóle cel leży u podstaw konstrukcji w postaci zatrzymania egzekwowania orzeczenia. W orzecznictwie i literaturze najczęściej podnosi się, że wstrzymanie wykonania wyroku może nastąpić jedynie wyjątkowo, gdy ujawnią się okoliczności świadczące o tym, że bezzwłoczne podjęcie czynności wykonawczych 
pociągnie za sobą nieodwracalne i niepowetowane skutki dla jednostki $\mathrm{i}^{13}$. Trzeba jednak pamiętać, że teza ta jest prezentowana w judykaturze zwykle na kanwie odpowiedzi na pytanie, czy Sąd Najwyższy winien wstrzymać egzekwowanie orzeczenia do czasu rozpoznania kasacji. Przytoczone twierdzenie może być przykładowo aktualne również w postępowaniu w przedmiocie odroczenia wykonania kary. W ich bowiem toku sąd pierwszej instancji decyduje się na wstrzymanie wykonania wyroku z uwagi na fakt, że skazany w dostateczny sposób uprawdopodobnił, że natychmiastowe wykonanie kary mogłoby pociągnąć za sobą zbyt ciężkie skutki dla niego lub jego rodziny. W takich bowiem sytuacjach osadzenie w jednostce penitencjarnej potencjalnie prowadzi do nieodwracalnych i niepowetowanych następstw.

Należy jednak pamiętać, że zezwolenie na dozór elektroniczny, jak już wspomniano, nie jest uwarunkowane tym, by wykonanie kary w zakładzie karnym pociągało za sobą dla skazanego lub jego rodziny zbyt ciężkie skutki. W tym sensie osadzenie w jednostce penitencjarnej często nie będzie groziło spowodowaniem nieodwracalnych i niepowetowanych szkód. Nie musi to jednak oznaczać, że w takich sytuacjach nie powinno się stosować art. $9 \$ 4$ k.k.w. Jak się bowiem wydaje, użycie przywołanego przepisu powinno być uwarunkowane celem i przedmiotem konkretnego postępowania incydentalnego. Oznacza to, że jeśli złożono wniosek o zastosowanie dozoru elektronicznego, wówczas, rozważając aplikację art. $9 \$ 4$ k.k.w., winno się prognozować, czy istnieje wysokie prawdopodobieństwo, że zezwolenie na odbywanie sankcji izolacyjnej zostanie rzeczywiście udzielone. Jeśli odpowiedź na tak postawione pytanie okaże się twierdząca, wówczas należałoby wstrzymać wykonanie wyroku. Bezcelowe jest bowiem kontynuowanie procedury osadzenia wówczas, gdy istnieją realne szanse na to, że zezwolenie na wykonanie kary pozbawienia wolności w SDE zostanie ostatecznie udzielone. Oczywiste jest zaś, że egzekwowanie sankcji w systemie dozoru jest

13 Postanowienie SN z 26 września 2012 r., V KK 218/12, «Lex» nr 1220962; postanowienie SN z 27 stycznia 2009 r., IV KK 433/08, «Lex» nr 1615312; postanowienie SN z 27 stycznia 2009 r., II KK 3/09, «Lex» nr 1615253; postanowienie SN z 20 czerwca 2006 r., II KK 224/06, «Lex» nr 610373; postanowienie SN z 8 stycznia 2004 r., II KK 287/03, «Lex» nr 162370. 
przejawem użycia łagodniejszego środka przymusu niż umieszczenie skazanego w zakładzie karnym. Skoro zaś w danej sytuacji bardziej celowe jest zastosowanie względniejszego instrumentu ograniczającego prawa i wolności jednostki, to natychmiastowe egzekwowanie kary izolacyjnej w surowszym reżimie mogłoby godzić w wyprowadzaną $\mathrm{z}$ art. 2 i art. 31 ust. 3 Konstytucji RP zasadę proporcjonalności. Organy postępowania wykonawczego nie powinny bowiem stosować najbardziej surowych środków przymusu, gdy nie jest to konieczne z uwagi na fakt, że do osiągnięcia określonego celu (w tym wypadku celów leżących u podstaw wykonania kary pozbawienia wolności) ${ }^{14}$ wystarcza łagodniejsza reakcja represyjna. Winny one więc dążyć do minimalizacji dolegliwości instrumentów ograniczających konstytucyjnie chronione uprawnienia lub wolności.

Przekładając tezy zawarte $\mathrm{w}$ dwóch poprzednich akapitach na zasadniczy przedmiot rozważań, należy podkreślić, że co do zasady to sąd penitencjarny ma najlepsze możliwości w zakresie oceny szans (rokowań) na udzielenie zezwolenia na odbywanie kary pozbawienia wolności w SDE, gdyż zwykle dysponuje najbardziej pełnymi informacjami koniecznymi do podjęcia tego rodzaju decyzji. Z kolei zdolności sądu pierwszej instancji w tym obszarze najczęściej będą ograniczone. Zatem fakt, że sąd penitencjarny jest $\mathrm{z}$ reguły najlepiej zorientowany w sytuacji prawnej skazanego z perspektywy podjęcia decyzji o zgodzie na wykonywanie sankcji izolacyjnej w formie dozoru, stanowi kolejny argument za tezą, iż właśnie to ten organ jurysdykcyjny powinien być właściwy do wydania postanowienia, o którym mowa w art. $9 \$ 4$ k.k.w. Taki punkt widzenia należy więc ostatecznie zaaprobować.

Warto dodać, że w praktyce występują przypadki, w których skazany lub jego obrońca, składając wniosek o udzielenie zezwolenia na

14 Twierdzenie, że zezwolenie na wykonywanie kary pozbawienia wolności w SDE może być udzielone wtedy, gdy jest to zgodne z celem tejże sankcji, prezentowane jest zarówno w orzecznictwie, jak i piśmiennictwie (postanowienie SA w Krakowie z 11 kwietnia 2012 r., II AKzw 287/12, «Lex» nr 1212403; postanowienie SA w Szczecinie z 10 maja 2017 r., II AKzw 544/17, «Lex» nr 2536214; K. DĄBKIEwiCz, Komentarz do art. 43 la k.k.w., [w:] K. DĄBKIEWICZ, Kodeks karny wykonawczy. Komentarz, Warszawa 2018, tezy 10 i 11). 
odbywanie kary pozbawienia wolności w SDE, nie tylko wnioskuje o wstrzymanie wykonania wyroku w toku postępowania przed sądem penitencjarnym, lecz - działając $\mathrm{z}$ tzw. ostrożności procesowej - jednocześnie wnosi w odrębnym piśmie procesowym o to samo do sądu pierwszej instancji. Tego rodzaju sposób postępowania może prowadzić do wielu niepożądanych rezultatów. W skrajnych przypadkach możliwe jest na przykład, że sąd penitencjarny odmówi zastosowania art. $9 \$ 4$ k.k.w., zaś sąd pierwszej instancji ów przepis aplikuje, wstrzymując w ten sposób wykonanie kary pozbawienia wolności do czasu wydania orzeczenia w przedmiocie dozoru. W przypadku przyjęcia powyższej perspektywy, że tylko sąd penitencjarny jest właściwy do powstrzymania natychmiastowego egzekwowania sankcji izolacyjnej, tego rodzaju problemów można niewątpliwie uniknąć.

Powstaje natomiast pytanie, jak należy postąpić, gdy do sądu pierwszej instancji wpłynie wniosek o zastosowanie art. $9 \$ 4$ k.k.w. oparty wyłącznie na argumencie, że został uprzednio złożony wniosek o wyrażenie zgody na odbywanie kary pozbawienia wolności w SDE. Można na pierwszy rzut oka twierdzić, że wówczas rzeczony organ procesowy winien - w oparciu o art. $35 \S 1$ k.p.k. w zw. z art. $1 \S 2$ k.k.w. - uznać się za niewłaściwy i przekazać skierowaną do niego sprawę według właściwości. Wydaje się jednak, że taki punkt widzenia nie jest trafny. Trzeba bowiem zauważyć, że skoro wszczęto już uprzednio postępowanie incydentalne $\mathrm{w}$ przedmiocie udzielenia zezwolenia na odbywanie kary w SDE, to już w chwili tego wszczęcia sąd penitencjarny stał się władny do wydania decyzji w oparciu o art. $9 \$ 4$ k.k.w. (która może być przecież wydana zarówno na wniosek, jak i z urzędu $)^{15}$. W takiej sytuacji sprawa wstrzymania wykonania wyroku zawisła już przed właściwym organem procesowym, a więc (z uwagi na powstanie stanu zawisłości sprawy) bezcelowe jest jej przekazywanie według właściwości do sądu penitencjarnego. Wówczas sąd pierwszej instancji winien, na podstawie art. $15 \$ 1$ k.k.w., umorzyć postępowanie w przedmiocie zastosowania art. $9 \$ 4$ k.k.w.

15 K. Postulski, Wykonalność orzeczeń karnych waspekcie zasady humanitaryzmu i poszanowania godności ludzkiej skazanego, «Palestra» 58.11-12/2013, s. 161. 
Nieco inna sytuacja wystąpi wtedy, gdy skazany najpierw złoży wniosek o udzielenie zezwolenia na odbywanie kary pozbawienia wolności w SDE, następnie zaś - zawnioskuje do sądu pierwszej instancji o odroczenie wykonania sankcji izolacyjnej, powołując się na okoliczności wskazane w art. $151 \$ 1$ k.k.w., nie zaś na sam fakt wszczęcia postępowania o dozór. W takim przypadku, wskutek wszczęcia pierwszego postępowania, nie aktualizuje się lis pendens. Wówczas bowiem sąd penitencjarny oraz sąd pierwszej instancji nie procedują w tym samym przedmiocie. Jakjuż bowiem wskazano, inne okoliczności są brane pod uwagę w postępowaniu w przedmiocie dozoru elektronicznego, inne zaś w sprawie o odroczenie wykonania kary. Z tego właśnie powodu wspomniane organy procesowe, decydując o wstrzymaniu wyroku, biorą pod uwagę różne czynniki, przez co orzekają w odmiennym przedmiocie. Można natomiast zaryzykować twierdzenie, że jeżeli jeden ze wspomnianych sądów zdecydował się już skorzystać z art. $9 \$ 4$ k.k.w., drugi - z uwagi na brak praktycznej konieczności - nie powinien tego czynić. Jeśli bowiem jeden $z$ organów jurysdykcyjnych wstrzymał wykonanie wyroku w zakresie kary pozbawienia wolności, wówczas uczynienie tego samego przez kolejny $\mathrm{z}$ nich jest bezprzedmiotowe ${ }^{16}$. Niecelowe jest przecież wstrzymywanie wykonania orzeczenia, które nie podlega wykonaniu.

Podsumowując zaprezentowane powyżej rozważania, należy uznać, że w sytuacji, w której złożono wniosek o zezwolenie na wykonanie kary w SDE, właściwy do wstrzymania wyroku w zakresie sankcji izolacyjnej jest sąd penitencjarny, nie zaś sąd pierwszej instancji. Istotnym, lecz niejedynym argumentem przemawiającym za tą tezą jest fakt, że aktualnie do katalogu zawartego w art. $242 \$ 4$ k.k.w. in fine dodano między innymi art. $9 \$ 3$ k.k.w. Można mieć nadzieję, że zmiana ta pozwoli ujednolicić rozbieżną dziś praktykę. Zaprezentowane dotychczas argumenty pozwoliły zaś twierdzić, że rozwiązanie takie jest optymalne

16 O konieczności umorzenia postępowania wykonawczego w sytuacji, gdy stało się ono bezprzedmiotowe - por. postanowienie SA w Lublinie z 22 lipca 2009 r., II AKzw 592/09, «Lex» nr 524001; postanowienie SA w Krakowie z 10 maja 2019 r., II AKzw 162/19, «Lex» nr 2718753. 
zarówno z perspektywy skazanego, jak i prawidłowości działania wymiaru sprawiedliwości.

ROZWAŻANIA O USTALANIU SĄDU WŁAŚCIWEGO DO WSTRZYMANIA WYKONANIA WYROKU W ZWIĄZKU ZE ZŁOŻENIEM WNIOSKU O UDZIELENIE ZEZWOLENIA NA ODBYWANIE KARY POZBAWIENIA WOLNOŚCI W SYSTEMIE DOZORU ELEKTRONICZNEGO

\section{Streszczenie}

W artykule rozważono kwestię ustalania sądu właściwego do wstrzymania wykonania wyroku w związku ze złożeniem wniosku o udzielenie zezwolenia na odbywanie kary pozbawienia wolności w systemie dozoru elektronicznego. Ostatecznie stwierdzono, że właściwy do wykonania takiej czynności jest sąd penitencjarny, nie zaś sąd pierwszej instancji.

Some Reflections on the Determination of the Appropriate

Court to stay a Prison Sentence Following the Offender's Application to serve His Sentence Subject to the Electronic Monitoring System

\section{SUMmARY}

The article considers the question which court is empowered under Polish law to stay a sentence of imprisonment if the offender submits an application to serve his sentence with the use of the electronic monitoring system. It concludes that the appropriate court empowered to take such decisions is the penitentiary court, not the court of first instance.

Słowa kluczowe: dozór elektroniczny; wstrzymanie wykonania wyroku; kara pozbawienia wolności.

Keywords: electronic monitoring system; stay of sentence; imprisonment. 


\section{Literatura}

DĄBKIEwiCz K., Komentarz do art. 43 la k.k.w., [w:] K. DĄBKIEwiCz, Kodeks karny wykonawczy. Komentarz, Warszawa 2018, tezy 10 i 11., s. 00-000.

Kuć M., Prawo karne wykonawcze, Warszawa 2017, s. 56-61

GóRsKi A., Wykonanie kary w systemie dozoru elektronicznego a przestępstwo samouwolnienia (uwagi na marginesie wyroku Sąu Najwyższego, I KZP 3/17), «PiP» 74.4/2019, s. 79-87.

Postulski K., Właściwość sądu w postępowaniu karnym wykonawczym, «Prokuratura i Prawo» 5/2010, s. 54-76.

Postulski K., Wykonalność orzeczeń karnych w aspekcie zasady humanitaryzmu i poszanowania godności ludzkiej skazanego, «Palestra» 58.11-12/2013, s. 155-167.

Zgoliński I., [w:] Kodeks karny wykonawczy. Komentarz, red. J. LACHowski, Warszawa 2018, s. 63-67. 